\title{
Stability of Large Thickened, Non-Segregated Tailings Slopes
}

\author{
A.L. Li Golder Associates Ltd, Canada \\ K. Been Golder Associates Inc., United States of America \\ D. Ritchie Golder Associates Ltd, Canada \\ D. Welch Golder Associates Ltd, Canada
}

\begin{abstract}
The growing trends in tailings management are to eliminate ponded water on top of tailings and to thicken tailings to conserve water and minimise the amount of water that has to be managed. There are various degrees of thickening ranging from a high density, non-segregated slurry, to a paste and filtered tailings.

Thickened tailings, with a consistency of a high density, non-segregated slurry or a paste can be safely deposited at slopes between $2-10 \%$ in thin layers that allow for desiccation with relatively small containment dams at the toe. However, stability is a concern, especially for large tailings deposits because the deposited properties can not accurately be predicted beforehand. Empirical relationships have not been developed because there is insufficient field data.

This paper discusses the stability of thickened tailings stacks (slopes) in both the short-term during operation and long-term in the closure mode. The authors have developed an innovative design methodology based on critical state soil mechanics fundamentals that can predict the stability of thickened tailings slopes and the change in the factor of safety with time. This tool can also be used to carry out sensitivity analyses for different operational conditions and different tailings properties so that deposition strategies can be optimised. Thin layer deposition and desiccation are necessary to ensure the stability of these slopes. A feature of the method is that the deviations from the design assumptions are evident shortly after deposition commences allowing time to implement changes.
\end{abstract}

\section{Introduction}

The mining industry is responding to pressures for change in mine waste management by developing innovative methods to dispose of tailings, conserve water, reduce risk and be more responsive to the ever increasing environmental and social concerns. Failures and non-compliance can have serious adverse environmental and social impacts that result in losses of production, reputation, investor confidence and a high cost of clean-up and remediation. The pressures for change are also being driven by sustainability issues and the 'Equator Principles' that lending agencies commonly adhere to. Project financing is now linked to sustainable development.

The current trends are to reduce or even eliminate ponded water on top of tailings and to thicken tailings to facilitate alternative disposal configurations. Eliminating ponded water greatly reduces the risk of catastrophic failures, especially if people are living downstream of the facility, and thickening has many benefits including:

- Less water to manage, treat and discharge to the environment (in wet climates).

- Water conservation from thickening for reuse in the mill (in dry climates).

- A reduced need for large expensive dams.

- Less adverse social and environmental impacts (a sustainability issue).

- More potential disposal sites to choose from (topographic containment is not as critical).

- A smaller watershed for the disposal site to minimise runoff. 
- A smaller footprint to reduce the area of disturbance.

- Flexibility to extend the life of a facility.

- Less long-term care and maintenance.

Conventional slurry typically comes out of a mill at discharge slurry densities between 30 and $50 \%$ solids by mass. For typical hard rock tailings the thickening levels beyond this are high density, non-segregated slurry (60-65\% solids that can be moved with centrifugal pump), paste ( $>70-75 \%$ solids that has to be moved with a positive displacement pump as plug flow); and filtered tailings (typically $>75-80 \%$ solids that has to be moved on a conveyor belt or by truck).

Thickened and paste tailings can be transported by pipelines and stacked using thin layer deposition. Thin layer deposition and desiccation are essential to increase the strength before placing the next layer to inhibit flow. If the conditions are adequate for desiccation (drying) to the shrinkage limit, then static liquefaction can potentially be precluded. However, for wet or high production operations, drying to the shrinkage limit may not be possible. Therefore, a design approach is required to provide a rational basis for selecting the target slope with flexibility to adjust the deposition during operations if required.

\section{Tailings depositional slopes}

The deposition of conventional tailings slurry generates a concave beach profile, typically with a $0.5-2.0 \%$ slope close to discharge points and as flat as $0.1 \%$ at the bottom of the beach, with the overall beach slope typically less than 1\% due to low solids concentration and segregation of particles (Vick, 1990; Blight, 1994). Conventional tailings deposits are highly layered and heterogeneous with the coarser particles settling near discharge points and finer particles settling farther away. Stability of the downstream slope of the tailings dam is evaluated to ensure containment. However, stability of the tailings beach is generally not considered because deposition is below the crest of containment structures.

Medium to high density tailings slurries have little or no segregation and liquid/solids separation upon deposition. The non-segregating characteristics significantly improve the slope angle and the homogeneity of the tailings deposit. Thickened tailings with high solids concentration exhibits viscous flow behaviour during transportation and deposition and can be approximated as a Bingham fluid. A paste has a higher yield stress but is still pumpable with a positive displacement pump (Jewell et al., 2002).

The discharge of non-segregated tailings generally forms channel flow close to the discharge point and then spreads to sheet flow. Both channel flows and sheet flows are generally turbulent when the velocity is high but become laminar before coming to rest. Eventually an equilibrium slope of the thickened tailings is developed which depends on many factors that include density of thickened tailings, grain size distribution, ore type, discharge method, rate of rise, thickness of tailings layer and climatic conditions.

An increase in the tailings depositional slope increases the storage capacity. Since the development of thickened tailings disposal by Robinsky (1975), it has been shown that thickening permits the tailings slurry to form tailings stacks with relatively uniform beach slopes typically from 2 to $5 \%$ for thickened tailings and up to 10\% for paste tailings (Robinsky, 1999; Williams et al., 2008; Golder Associates Ltd, 2008).

Table 1 gives a summary of case histories reported in the literature and Golder Associates internal data base for tailings depositional slopes that have been achieved for non-segregated tailings disposal (thickened and paste tailings but not filtered tailings) disposal. Figure 1 shows an approximate correlation between the depositional slope and the slurry density (i.e. solids concentration). There is a trend of increasing slope with increased slurry density although the achieved slopes cover a wide range. 
Table 1 Summary of thickened/paste tailings disposal facilities and depositional slopes

\begin{tabular}{|c|c|c|c|c|c|c|c|c|}
\hline \multirow{2}{*}{ Mine } & \multirow{2}{*}{ Location } & \multirow{2}{*}{ Ore Type } & \multirow{2}{*}{$\begin{array}{c}\text { Production } \\
\text { Rate } \\
(\mathbf{M t} / \mathbf{y r})\end{array}$} & \multirow{2}{*}{$\begin{array}{c}\text { Tailings } \\
\text { Slurry } \\
\text { Density } \\
\text { (\% solids) }\end{array}$} & \multirow{2}{*}{ Disposal Scheme } & \multicolumn{2}{|c|}{ Depositional Slope } & \multirow{2}{*}{ Reference } \\
\hline & & & & & & $\begin{array}{l}\text { Max } \\
(\%)\end{array}$ & $\begin{array}{c}\text { Typical Range } \\
\text { (\%) }\end{array}$ & \\
\hline Kidd Metsite & Ontario, Canada & Copper / Zinc & 2.92 & $60-65$ & Central tailings discharge & 5.7 & $2.0-4.0$ & Golder Associates 2008 \\
\hline Bulyanhulu & Tanzania & Gold & 0.7 & $73-79$ & Central tailings discharge & 11.0 & $6-8$ & Golder Assciates 2008 \\
\hline Les Mines Selbaie & Abitibi, Quebec & Copper/Gold/Silver & 0.54 & 60 & Central tailings discharge & 4.0 & $4 \%$ & Wood \& McDonald 1986 \\
\hline Elura & NSW, Australia & Zinc & 1.0 & 60 & Central tailings discharge & 1.7 & & Williams \& Seddon 1999 \\
\hline Peak Gold Mine & NSW, Australia & Gold & 0.4 & $55-62$ & Central tailings discharge & $2.5+$ & $1.5-2.0$ & Williams \& Seddon 1999 \\
\hline Union Reefs & NT, Australia & Gold & $2.0-3.0$ & $<55$ & Down valley discharge & 0.9 & & Williams \& Seddon 2008 \\
\hline McArthur River & NT, Australia & Lead & 2.4 & 60 & Central tailings discharge & 1.0 & & Williams \& Seddon 1999 \\
\hline Cluff Lake & Sask., Canada & Uranium & 0.32 & 52 & Down valley discharge & 3.0 & & Oxenford \& Lord 2006 \\
\hline Ernest Henry & Qld, Australia & Copper & 7.0 & 75 & Central tailings discharge & 1.1 & & Wiliams \& Seddon 1999 \\
\hline Mount Keith & WA, Australia & Nickel & 10.5 & 44 & Central tailings discharge & 2.0 & & Williams \& Seddon 1999 \\
\hline Blendevale & WA, Australia & Lead & 1.5 & 65 & Central tailings discharge & 1.5 & & Williams \& Seddon 1999 \\
\hline Warkworth & NSW, Australia & Ash & 0.1 & 70 & Side hill & 5.0 & & Williams et al. 2008 \\
\hline Ekati & Canada & Diamond & 1.6 & 40 & Surface & 1.0 & 1 & Williams et al. 2008 \\
\hline Strathcona & Canada & Nickel & 0.5 & 45 & & 1.5 & $1.25-1.5$ & Williams et al. 2008 \\
\hline Century & Qld, Australia & Zinc & 4.3 & $52-58$ & Down valley discharge & 1.0 & $0.6-1.0$ & Williams et al. 2008 \\
\hline Sunrise Dam & WA, Australia & Gold & 3.6 & 64 & Central tailings discharge & 2.0 & $1.0-2.0$ & Williams \& Seddon 2008 \\
\hline Myra Falls & Canada & Copper / Zinc & & $65-68$ & & 3.0 & & Oxenford \& Lord 2006 \\
\hline Kimberley & South Africa & Diamond & 8.6 & $44-57$ & Central tailings discharge & 1.5 & 1 & Houman \& Johnson 2003 \\
\hline Osborne & Qld, Australia & Copper / Gold & 1.34 & $72-76$ & Central tailings discharge & 4.0 & 3 & McPhail et al. 2004 \\
\hline Miduk & Iran & Copper & 4.8 & 63 & Down valley discharge & 2.5 & $2.3-2.4$ & Williams et al. 2008 \\
\hline Granites & Australia & Gold & 0.2 & $55-60$ & In pit & 2.0 & na & Williams et al. 2008 \\
\hline $\begin{array}{l}\text { Vaundreuil } \\
\text { (Jonquiere) }\end{array}$ & Quebec, Canada & Bauxite & 0.45 & 45 & & 4.0 & $3.0-4.0$ & Oxenford \& Lord 2006 \\
\hline Aughinish & Ireland & Bauxite & 1.7 & 63 & Central tailings discharge & 2.7 & $1.5-2.7$ & Williams et al. 2008 \\
\hline
\end{tabular}

With the advantages of the depositional behaviour of non-segregated tailings and elimination of large tailings ponds, thickened and/or paste tailings can be stacked as a cone-shaped deposit using a central discharge method for a relatively flat tailings basin. The tailings can also be stacked in a basin with a sloping valley floor by discharging tailings from high grounds into the valley, which can be contained using a dam at the toe of the tailings stack. Depending on the surface length of the tailings stack and the size of the project, the height of a thickened/paste tailings stack above containment toe dams can be substantial. For example, the height of the tailings stack would be $100 \mathrm{~m}$ for a 5\% slope and a $2000 \mathrm{~m}$ long tailings surface. Therefore, the physical stability of thickened/paste tailings stacks is an important consideration in design. Both the longterm and short-term stability of the tailings stacks need to be addressed. 


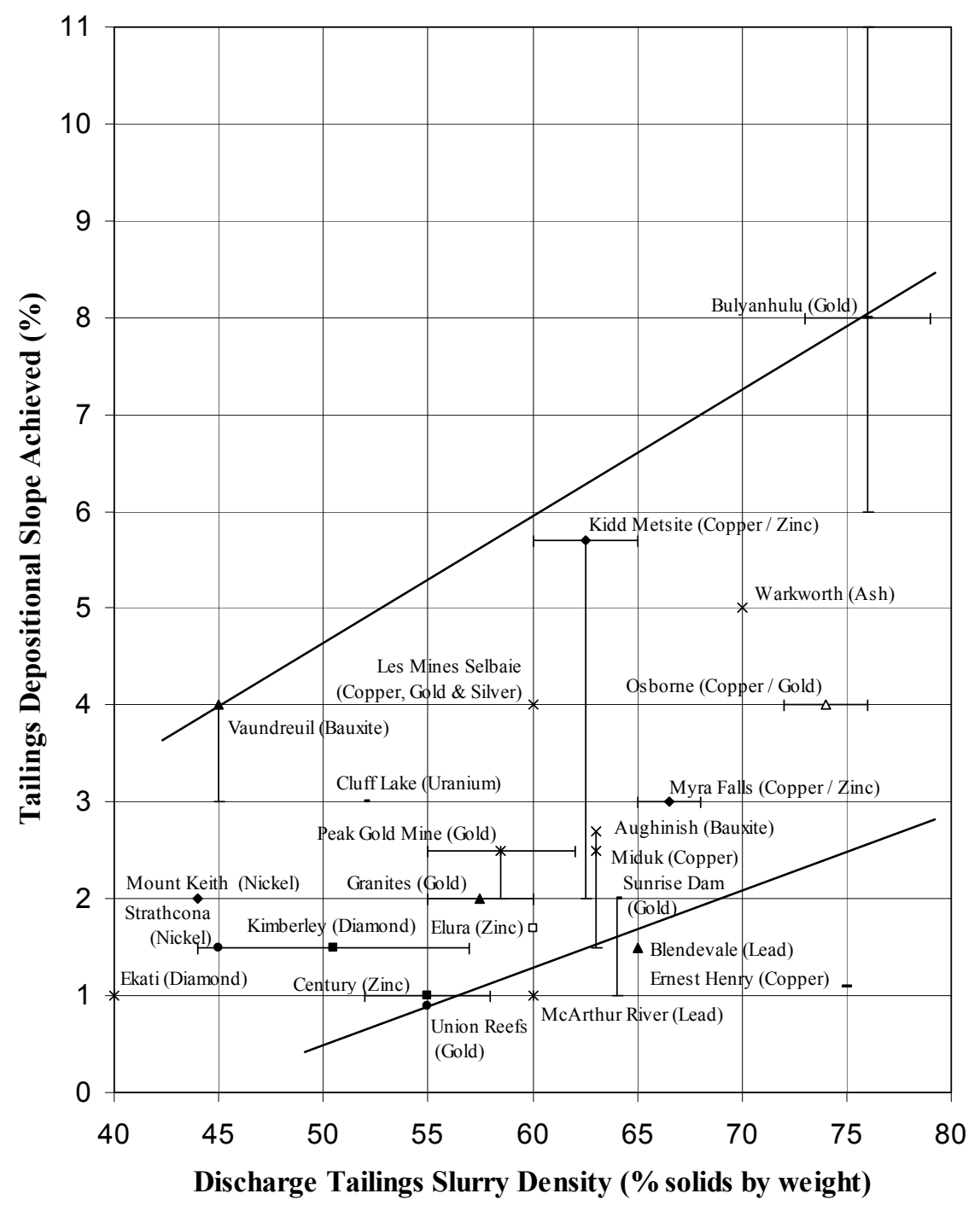

Figure 1 Variation of tailings depositional slope with tailings slurry density

\section{$3 \quad$ Stability and consolidation modelling of non-segregated tailings stacks}

The prediction of the stability of tailings stacks is a highly complex issue due to the fact that the properties of the deposited thickened tailings cannot be accurately predicted in advance. In the literature, there is paucity of research on the stability of non-segregated tailings stacks. Previous studies show that the stability of thickened tailings stacks is most critical when tailings liquefy under seismic conditions (Poulos et al., 1985; McMahon et al., 1996; Seddon et al., 1999; Fourie, 2006; Barrera and Riveros, 2006; Seddon, 2007) and efforts were made to predict the safety margins. However, the stability of tailings stacks under both shortterm and long-term conditions has not been fully addressed. Both static loading and seismic loading can cause an increase in excess pore pressure, reduce the effective stress and potentially cause liquefaction of the tailings. The strength of the tailings reduces to a residual strength from peak strength after it is liquefied (Seed, 1987).

A tailings stack is stable under static long-term (drained) conditions, since the slope angles of the tailings stacks (Figure 1) are low in comparison to the friction angles of the tailings materials. A tailings stack would only fail when liquefaction occurs and triggers a 'flow' slide. Liquefaction can be caused by seismic events or by static loading as more material is added to the stack. A post liquefaction 'flow' slide would only be developed when the residual strength of the liquefied tailings is less than the shear stress imposed by the slope of the tailings deposit. 
Numerous researchers (Been and Jefferies, 1985; Seed, 1987; Seed and Harder, 1990; Wride et al., 1999) have shown that the residual strength of liquefied sands is a function of the in situ state (void ratio). However, the void ratio of tailings is not a single value, due to consolidation, and consideration of the problem requires a model that includes the effect of stress and void ratio changes on tailings behaviour. Critical state soil mechanics provides such a soil model for tailings behaviour and liquefaction (Been and $\mathrm{Li}$, 2009). The authors have developed a new design tool for stability of tailings stacks based on a critical state framework.

The main assumptions for the analytical model developed are:

- The behaviour of the tailings can be described using soil mechanics theories developed for sandy soils and extended to silty soils.

- The tailings can potentially liquefy under static loading conditions during deposition and under the design seismic event during and after operation. This assumption is reasonably conservative considering the consequences.

The proposed design tool is illustrated using an analysis example for a thickened tailings stack, which is to be deposited at a design slope of 5\% at an average rate of rise of $8 \mathrm{~m}$ per year in a valley over a mine life of 22.5 years. The final thickness of the deposit is to be $180 \mathrm{~m}$. The length of the tailings slope is $3850 \mathrm{~m}$ and the height of the tailings slope is to be $192.5 \mathrm{~m}$ above the crest of the containment dam at its toe.

\subsection{Behaviour of tailings and residual strength}

The behaviour of the sands under undrained conditions can be described using critical state soil mechanics (Casagrande, 1975; Castro and Poulos, 1977; Been et al., 1985; Jefferies and Been, 2006). The critical state is an ultimate state that the soil reaches under shearing. The critical state is represented using a critical state line (CSL) in a void ratio - effective mean stress space in a semi-log form $\left(e-\ln \sigma_{m}^{\prime}\right)$ (Figure 2):

$$
e_{c}=\Gamma-\lambda \ln \left(\sigma_{m}^{\prime}\right)
$$

where $e_{c}$ is the critical void ratio, which is the void ratio of the sands at the critical state; $\Gamma$ is the reference void ratio on CSL at $1 \mathrm{kPa} ; \lambda$ is the slope of the critical state line; and $\sigma_{\mathrm{m}}{ }^{\prime}$ is the mean effective stress.

The behaviour of sands is governed by the state parameter, $\psi$, defined as the void ratio difference between the initial sand state, $e_{0}$, and the critical state, $e_{c}$, at the same mean effective stress (Been and Jefferies, 1985).

$$
\psi=e_{c-} e_{0}
$$

Soils exhibit contractive behaviour when the state parameter is positive and dilative behaviour when the state parameter is negative.

The residual strength of the liquefied sands can be estimated using the following equation proposed by Jefferies and Been (2006):

$$
\frac{s_{r}}{\sigma_{m}^{\prime}}=\frac{M}{2} \exp \left(-\frac{\psi}{\lambda}\right)
$$

where $s_{r}$ is the residual strength; and $M$ is the critical friction ratio.

The residual strength predicted using the above equation agrees reasonably well with mobilised shear strength from the case history data for positive values of $\psi$ (Jefferies and Been, 2006), but has not been demonstrated to apply to negative values of $\psi$ for which shear localisation occurs. 


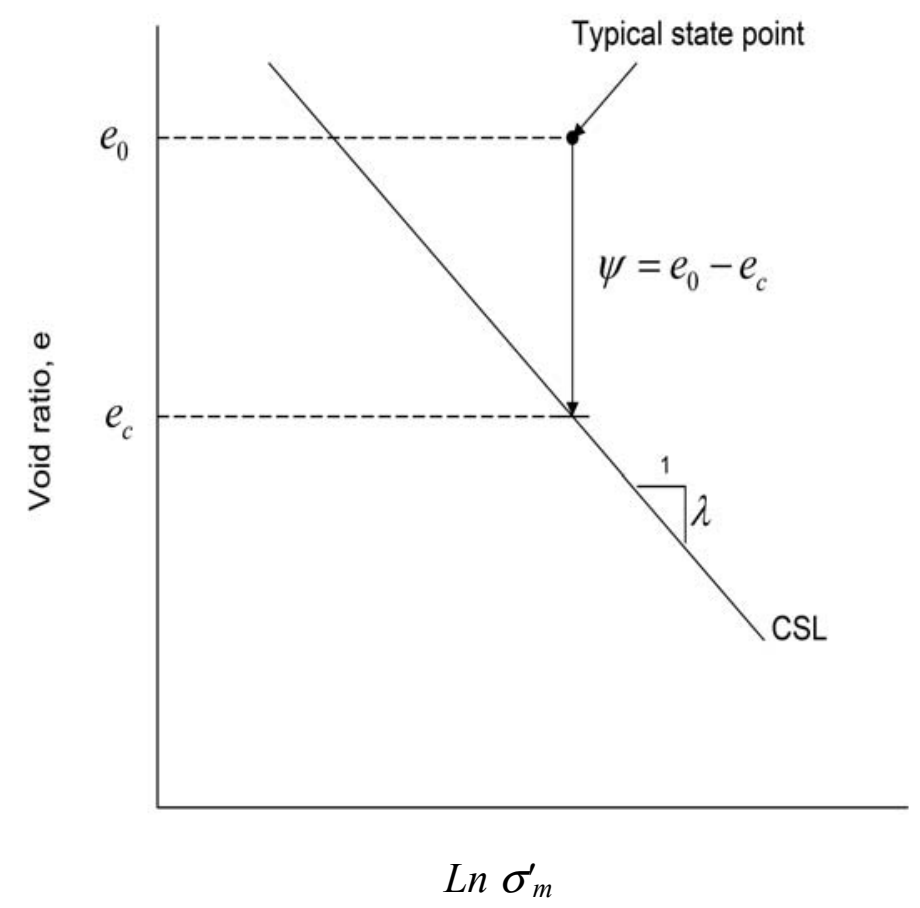

Figure 2 Definition of critical state line and state parameter (modified from Been and Jefferies, 1985)

\subsection{Consolidation of tailings}

A tailings deposit is developed during deposition of layers of very soft and loose tailings, which will consolidate under its own weight. The deposit will undergo large strains and drainage paths increase as thickness of the deposit gradually increases. Therefore, for a tailings slurry consolidation problem, the conventional Terzaghi consolidation theory becomes invalid due to the limitations on the strain and fixed drainage paths. The consolidation of the tailings under its self-weight is considered using the Lee and Gills (1981) approach. This approach is based on a finite strain consolidation theory (Gibson et al., 1967) with the following governing equation:

$$
\frac{\partial e}{\partial t}=-\frac{\partial}{\partial z}\left[\frac{k}{\rho_{f}(1+e)} \frac{d \sigma^{\prime}}{d e} \frac{\partial e}{\partial z}\right]-\left(\rho_{s}-\rho_{f}\right) \frac{d}{d e}\left(\frac{k}{\rho_{f}(1+e)}\right) \frac{\partial e}{\partial z}
$$

where $\mathrm{z}$ is the soil thickness (material coordinate); $\sigma^{\prime}$ is the effective stress; $\mathrm{k}$ is the hydraulic conductivity; $\rho_{s}$ is the unit weight of the tailings particles; and $\rho_{f}$ is the unit weight of the pore fluid.

For a constant rate of rise and a one way drainage boundary condition assuming that the bottom of the tailings deposit is impervious, the Lee and Gills (1981) solution for the void ratio change at any time during deposition and any depth is:

$$
\Delta e(y, T)=\frac{\beta C_{v}}{m} T\left[\left(\frac{T}{\pi}\right)^{1 / 2} \exp \left(\frac{-y^{2} T}{4}\right) \int_{0}^{\infty} \xi \tanh \left(\frac{\xi T}{2}\right) \cosh \left(\frac{\xi y T}{2}\right) \exp \left(\frac{-\xi^{2} T}{4}\right) d \xi-y\right]
$$

where $T$ is the time factor; $C_{v}$ is the consolidation coefficient; $y$ is the depth of tailings in Lagrangian coordinates; $\mathrm{m}$ is the rate of rise; $\mathrm{m}$ is the constant rate of deposition; and $\beta$ is the normalised compressibility. 
The void ratio change due to consolidation after deposition is solved as the following:

$$
\Delta e(y, T)=\beta m t\left[1-y-2 \sum_{n} c_{n} \cos \left[\left(\frac{2 n-1}{2}\right) \pi y\right] \exp \left[-\left(\frac{2 n-1}{2}\right)^{2} \pi^{2} T\right]\right]
$$

where the Fourier coefficients $c_{n}$ are a function of the time factor and depth; $\mathrm{n}=0,1,2, \ldots$

The Lee and Gills (1981) solutions are modified to include the nonlinear compressibility of the tailings during consolidation using numerical integration.

Figure 3 shows a series of consolidation curves for tailings samples with different initial void ratios prepared in the laboratory. Similar to the consolidation behaviour observed for normally consolidated sands (Jefferies and Been, 2000), the consolidation lines are approximately parallel to each other. As is shown on Figure 3, the tailings can have different initial states which also result in different final void ratios, i.e. there is not a single consolidation curve for this material.

Also shown on Figure 3 is the critical state line of the tailings which was measured using isotropically consolidated undrained and drained triaxial tests. A consolidation analysis was carried out to calculate the void ratio of the tailings deposit at the end of the mine life and at the end of consolidation for the tailings. The calculated void ratios were compared to the critical void ratio at the same mean effective stress on the CSL (Figure 3) to determine the state parameter.

Using Equation (3), the residual strength of the tailings can be determined based on the properties of the tailings and the state in the tailings deposit in various layers. Figure 4 shows the void ratio profile of the tailings after $100 \%$ consolidation with initial void ratio of 0.84 after desiccation, the profile of the state parameter, and the inferred residual strength ratio for the upper $100 \mathrm{~m}$ of the tailings deposit.

The ratio of residual strength to effective vertical stress was 0.13 and 0.22 up to $100 \mathrm{~m}$ depth for the tailings deposit, typically less than 0.15 from 10 to $50 \mathrm{~m}$ depths (assuming $\mathrm{K}_{0}=0.6$ ). The inferred $s_{r} / \sigma_{\mathrm{v}}^{\prime}$ ratio is within the range of 0.03 to 0.3 observed in field cases (Olson and Stark, 2002; Jefferies and Been, 2006). It should be noted that the ratio of residual strength to effective vertical stress of the tailings changes with time and depth due to the different state of the tailings in relation to the critical state line.

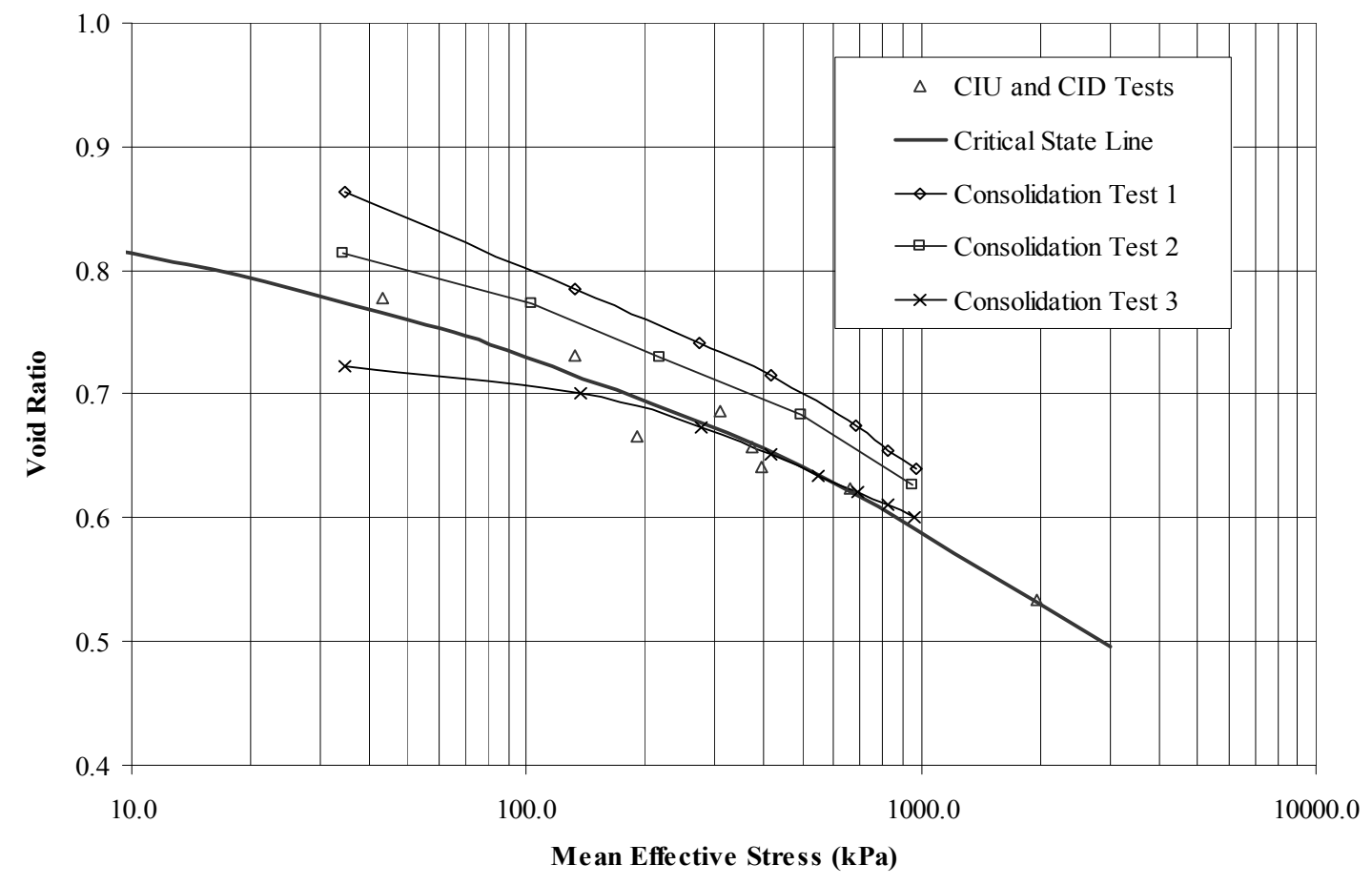

Figure 3 Results of triaxial compression tests and consolidation tests 


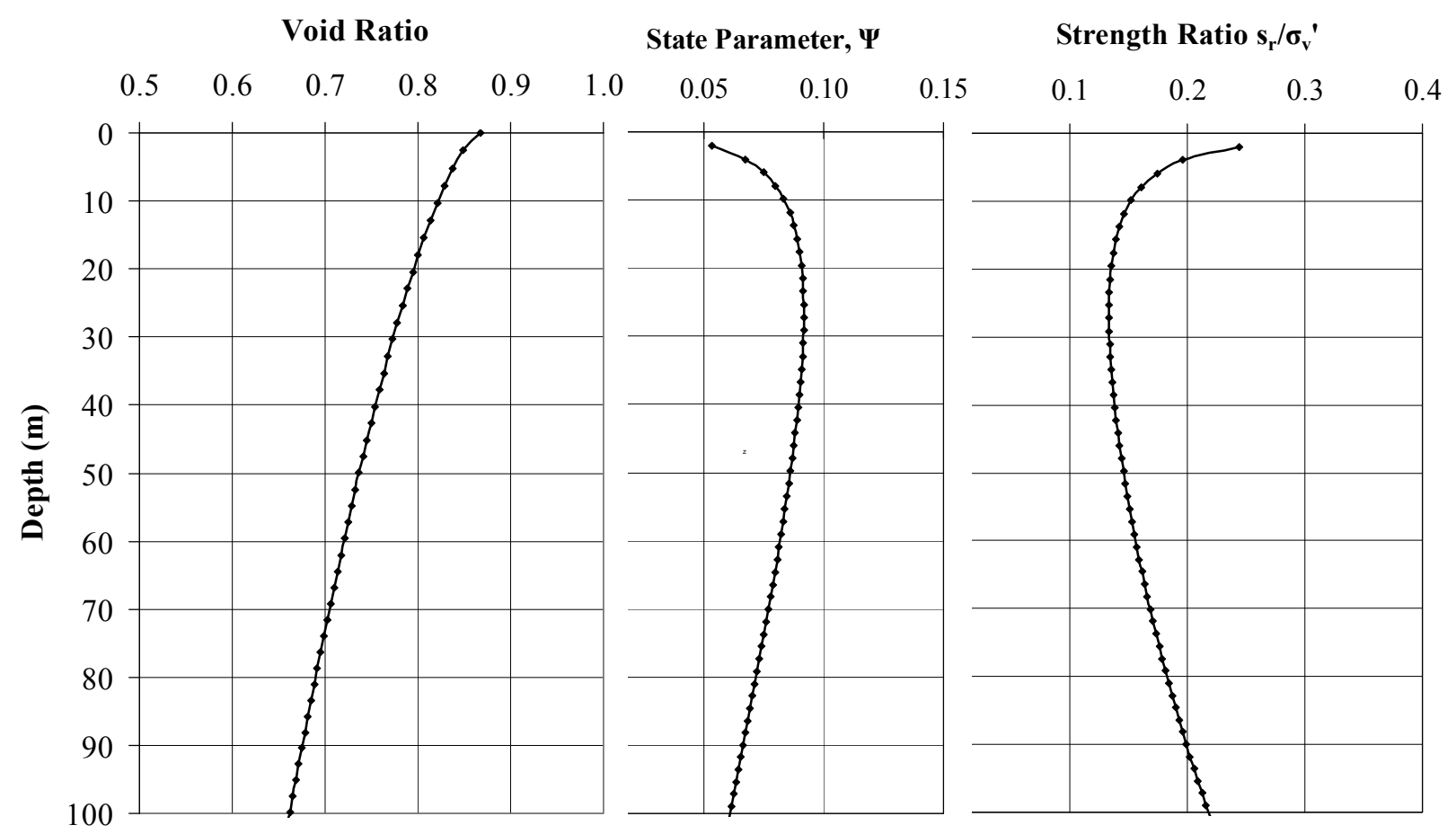

Figure 4 Profiles of void ratio, state parameter and residual strength ratio for a tailings deposit after $100 \%$ consolidation

\subsection{Stability predictions}

A limit equilibrium method for an infinite slope failure mechanism can be adopted considering the very long slope of the tailings stack. Since the residual strength of the tailings is a function of depth, the factor of safety will also change with depth of the sliding surface in the infinite slope. The factor of safety against failure at different depths can be calculated using the following derived equation for an infinite slope:

$$
F O S=\frac{s_{r}}{h \gamma \sin \alpha \cos \alpha}
$$

where $h$ is the depth of the slip surface; $\gamma$ is the saturated unit weight of the tailings deposit; and $\alpha$ is the slope angle of the tailings stack.

Using Equations (1) through (7), sensitivity studies can be carried out for different depositional slope angles and operating conditions (e.g. rates of rise). Figure 5 shows the results of a sensitivity study for the tailings examined in forms of the factor of safety profiles for the upper $100 \mathrm{~m}$ of tailings. Two deposition conditions were considered:

Deposition condition 1: Through thin layer deposition and desiccation, the initial conditions of the freshly deposited tailings achieve an initial void ratio of 0.76 before the tailings is buried by the next layer of deposited tailings. With this initial void ratio, the factor of safety is greater than 1.0 for a $5 \%$ slope at the end of mine life (solid square on Figure 5).

Deposition condition 2. This represents the tailings deposition only achieves an initial state with void ratio of 0.84 and the calculated factor of safety for the 5\% slope is lower than 1 during deposition. However it increases to values greater than 1.0 at 80 years after the deposition due to consolidation. 
(a) Factor of Safety at End of Mine Life Deposition Condition 1 (b) Factor of Safety at Different Time

Deposition Condition 2

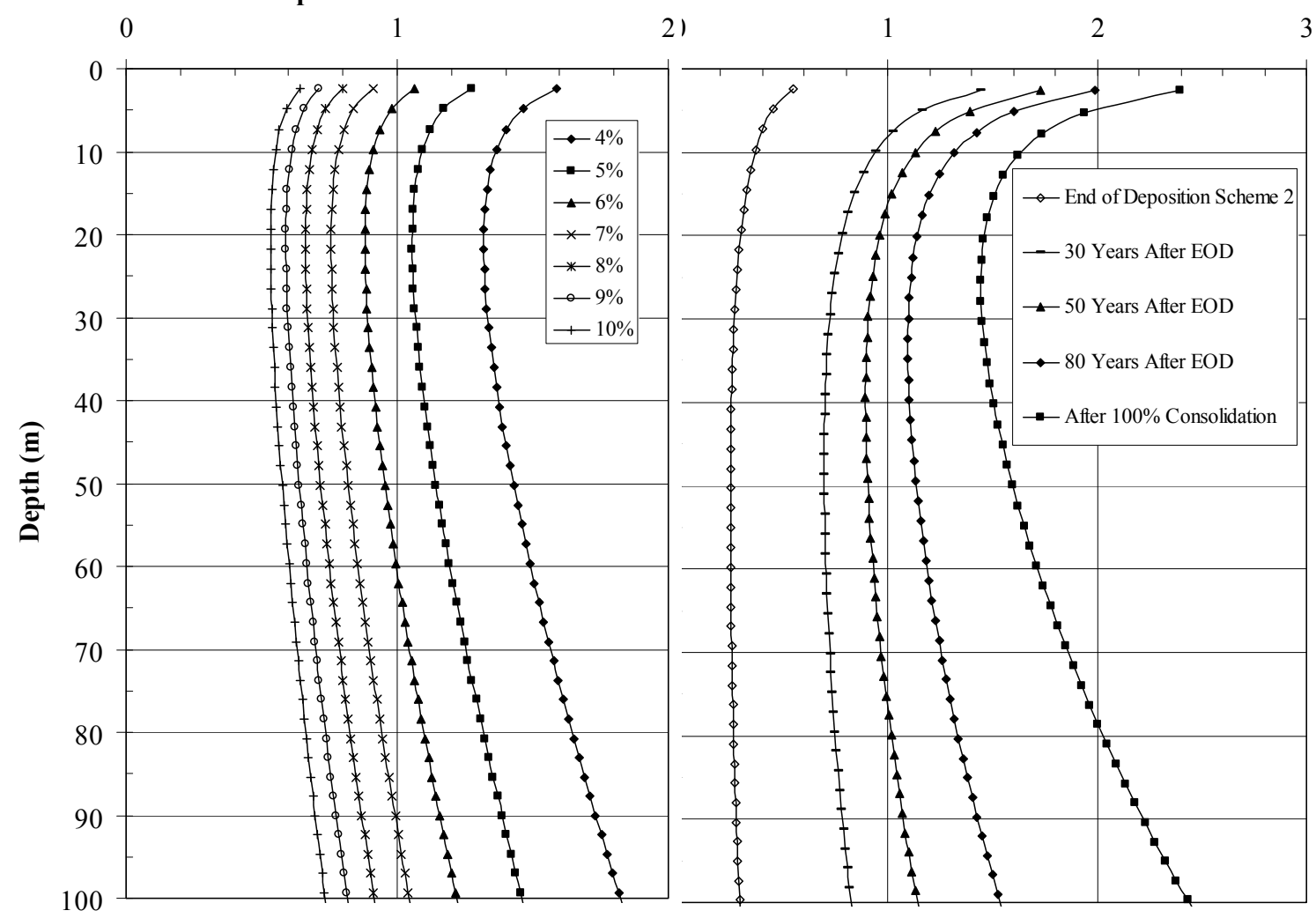

3

Figure 5 Profiles of the calculated factor of safety against 'flow' failure for deposition conditions 1 and 2

As can be seen on Figure 5, the factor of safety of the tailings stack deposited under Condition 1 reaches the lowest value at a depth of $20 \mathrm{~m}$ (Figure 5a) at the end of mine for different slope angles. Figure 5b shows that the depth with the lowest factor safety changes with time during consolidation of the tailings deposit. This provides insight on the spatial variation of the stability of the tailings stacks, which should be considered when designing mitigative measures to improve the stability.

\subsection{Initial void ratio and implications for operation}

As is discussed above, the initial void ratio has an effect on the stability of a non-segregated tailings stack. The initial void ratio of each fresh tailings layer depends on many factors including the climatic condition, rate of rise, deposition methods and layer thickness. Thin layer deposition allowing desiccation of the tailings is essential to achieve the required initial void ratio. For a given climatic condition and a rate of rise, laboratory drying testing and modelling can be used to establish the required number of the days for drying before placement of another tailings layer for tailings deposition for a given slope. During the early years of operation, in situ testing and tailings characterisation can be carried out to confirm the initial void ratio of the tailings and design assumptions. Therefore, the operation can be optimised to achieve the design requirements allowing mitigative measures to be implemented before problems arise.

\section{Conclusions}

Tailings management has imposed significant challenges to the mining industry with respect to social, environmental and economic impacts. Historical tailings dam failures and release of tailings and contaminated water, among other factors, are forcing the industry to change. The growing trends are to thicken tailings to conserve water and minimise potential risks associated with dam failure. 
Stacking non-segregated tailings at increased slope angles provides numerous benefits but it is paramount to ensure the stability of the tailings stack during operation and after closure. A new design approach is developed to infer stability of sloping thickened tailings deposits. The salient features of this approach are:

The capability to predict the time dependent stability of a tailings stack during operation or after closure (i.e. both short-term and long-term conditions).

Accounting for different operation conditions, such as the rate of rise of tailings deposition and different initial conditions of the tailings (i.e. initial void ratio and moisture) due to different climactic conditions.

Ability to carry out sensitivity analyses for different operational conditions and different tailings properties so that tailings deposition strategies can be optimised.

The initial condition of the tailings before burial during deposition is one of the key parameters that can affect the both short-term and long-term stability of the tailings stack. Tailings management and deposition strategies must be optimised to achieve thin layer deposition and maximise desiccation and consolidation. The method presented provides a basis for adapting deposition strategies and/or target slopes to satisfy stability requirements.

\section{References}

Barrera, S. and Riveros, C. (2006) Stability tailings beach slopes, Proceedings of the Ninth International Seminar on Paste and Thickened Tailings, R.J. Jewell, S. Lawson and P. Newman (eds), Australian Centre for Geomechanics, Perth, Australia, pp. 169-179.

Been, K. and Jefferies, M.G. (1985) A state parameter for sands. Géotechnique, 35 (2): pp. 99-112.

Been, K. and Li, A.L. (2009) Soil liquefaction and paste tailings, Proceedings of the Twelfth International Seminar on Paste and Thickened Tailings, R.J. Jewell, A.B. Fourie, S. Barrera and J. Wiertz (eds), Australian Centre for Geomechanics, Perth, Australia, pp. 281-290.

Been, K., Jefferies, M.G. and Hachey, J. (1985) The critical state of sands. Géotechnique, 41 (3): pp. 365-381.

Blight, G.E. (1994) The master profile for hydraulic fill tailings beaches, Transactions Institution of Civil Engineers, Geotechnics Engineering 107, pp. 27-40.

Casagrande, A. (1975) Liquefaction and cyclic deformation of sands, a critical review, Proceedings of the Fifth PanAmerican Conference on Soil Mechanics and Foundation Engineering, Buenos Aires, 5, pp. 79-133.

Castro, G. and Poulos, S.J. (1977) Factors affecting liquefaction and cyclic mobility. Journal of Geotechnical Engineering Division, ASCE, Vol. 103, GT6, pp. 501-516.

Fourie, A.B. (2006) Liquefaction potential of surface deposits of high density thickened tailings. Proceedings of the Ninth International Seminar on Paste and Thickened Tailings, R.J. Jewell, S. Lawson and P. Newman (eds), Australian Centre for Geomechanics, Perth, Australia, pp. 107-116.

Gibson, R.E., England, G.L. and Hussey, M.J.L. (1967) The theory of one dimensional consolidation of saturated clays. I. Finite non-linear consolidation of thin homogeneous layers, Géotechnique, 17: pp. 261-273.

Golder Associates Ltd (2008) Golder internal data base on thickened tailings disposal.

Houman, J. and Johnson, C. (2003) Commissioning and operation of the paste thickening farm at Kimberley Combined Treatment Plant, Proceedings of the Sixth International Seminar on Paste and Thickened Tailings, Australia Centre for Geomechanics, Perth, Australia, Section 12.

Jefferies, M.G. and Been, K. (2000) Implications for critical state theory from isotropic compression of sand, Géotechnique 50 (4): pp. 419-429.

Jefferies, M.G. and Been, K. (2006) Soil liquefaction, a critical state approach. Taylor \& Francis, London.

Jewell, R.J., Fourie, A.B. and Lord, E.R. (2002) Paste and Thickened Tailings - A Guide, Australian Centre for Geomechanics, Perth, Australia.

Lee, K. and Gills, G.C. (1981) The consolidation of a soil stratum, including self-weight effects and large strains. International Journal for Numerical and Analytical Methods in Geomechanics, 5: pp. 405-428.

McMahon, B., Phillips, J.T. and Hutton, W.A. (1996) The evaluation of thickened tailings in a seismic area, Tailings and Mine Waste, 1996, Fort Collins.

McPhail, G., Noble, A., Papageorgiou, G. and Wilkinson, D. (2004) Development and Implementation of Thickened Tailings Discharge at Osborne Mine, Queensland, Australia, Proceedings of the Seventh International Seminar on Paste and Thickened Tailings, A.B. Fourie, P. Slatter and A. Paterson (eds), Australian Centre for Geomechanics, Perth, Australia, Paper 27.

Olson, S.M. and Stark, T.D. (2002) Liquefied strength ratio from liquefaction flow failure case histories, Canadian Geotechnical Journal, 39: pp. 629-647. 
Oxenford, J. and Lord, E.R. (2006) Canadian experience in the application of paste and thickened tailings for surface disposal, Proceedings of the Ninth International Seminar on Paste and Thickened Tailings, R.J. Jewell, S. Lawson and P. Newman (eds), Australian Centre for Geomechanics, Perth Australia, pp. 93-106.

Poulos, S.J., Robinsky, E.I. and Keller, T.O. (1985) Liquefaction resistance of thickened tailings, Journal of Geotechnical Engineering, 111 (12): pp. 1380-1394.

Robinsky, E.I. (1975) Thickened discharge - a new approach to tailings disposal, Bulletin, The Canadian Institute of Mining and Metallurgy, December 1975, pp. 47-59.

Robinsky, E.I. (1999) Thickened tailings disposal in the mining industry, E.I. Robinsky Associates, 1999,210 p.

Seddon, K.D. (2007) Post-liquefaction stability of thickened tailings, Proceedings of the 10th International Seminar on Paste and Thickened Tailings, A.B. Fourie and R.J. Jewell (eds), Australian Centre for Geomechanics, Perth, Australia, pp. 395-406.

Seddon, K.D., Murphy, S.D. and Williams, M.P.A. (1999) Assessment of Liquefaction Flow Stability of a Thickened Tailings Stack, Proceedings of the Eighth Australia New Zealand Conference on Geomechanics, pp. 521-528.

Seed, H.B. (1987) Design problems in soil liquefaction, Journal of Geotechnical Engineering, 113 (GT8): pp. 827-845.

Seed, R.B. and Harder, Jr., L.F. (1990) SPT Based analysis of cyclic pore pressure generation and undrained residual strength H.B, Seed Memorial Symposium, May 1990, pp. 351-376.

Vick, S.G. (1990) Planning, design, and analysis of tailings dams, BiTech Publishers Ltd., Vancouver, Canada.

Williams, M.P.A. and Seddon, K.D. (1999) Thickened tailings discharge: A review of Australian experience, Tailings and Mine Waste 99, Fort Collins.

Williams, M.P.A., Seddon, K.D. and Fitton, T.G. (2008) Surface disposal of paste and thickened tailings - A brief history and current confronting Issues, Proceedings of the 11th International Seminar on Paste and Thickened Tailings, A.B. Fourie, R.J. Jewell, P. Slatter and A. Paterson (eds), Australian Centre for Geomechanics, Perth, Australia, pp. 143-164.

Wood, K.R. and McDonald, G.W. (1986) Design and operation of thickened tailings disposal system at Les Mines Selbaie, CIM Bulletin, 79 (895): pp. 47-51.

Wride, C.E., McRoberts, E.C. and Robertson, P.K. (1999) Reconsideration of case histories for estimating undrained shear strength in sandy soils, Canadian Geotechnical Journal, 36 (5): pp. 907-933. 